Supplement of Earth Syst. Sci. Data, 10, 951-968, 2018

https://doi.org/10.5194/essd-10-951-2018-supplement

(C) Author(s) 2018. This work is distributed under

the Creative Commons Attribution 4.0 License.

(c) (1)

Supplement of

\title{
Historical gridded reconstruction of potential evapotranspiration for the UK
}

Maliko Tanguy et al.

Correspondence to: Maliko Tanguy (malngu@ceh.ac.uk)

The copyright of individual parts of the supplement might differ from the CC BY 4.0 License. 


\section{SUPPLEMENTARY MATERIAL}

\section{Section S1. Assumptions of ordinary least squares (OLS)}

OLS method was used to calibrate the PET equations.

The assumption of homoscedasticity (variance of residual is constant) is violated, as the Breusch Pagan test (Breusch and Pagan, 1979) rejects the null hypothesis. The residuals (or errors) are larger when PET is large (spring/summer) than when PET is small (autumn/winter), as is hinted from Fig. A3 of the supplementary information. This is inevitable, as we know that the full variability of PET can't be explained solely by temperature, and other climatic variables, which have seasonal variations, such as wind speed, cloud cover, humidity, etc., aren't taken into account in temperature-based equations, and have a strong influence in PET.

This is why we have tried the 12P-ind and 12P-GB calibration approach (Fig. 3), which removed the heteroscedasticity problem by calibrating the equations separately for each individual month (Breusch Pagan test does not reject the null hypothesis in this case, suggesting homoscedasticity assumption is correct). However, the resulting calibrated equation proved not to be any superior to the globally calibrated version which violated the homoscedasticity assumption, according to our two performance assessment metrics NSE and MAPE (as shown in Fig. 4).

Heteroscedasticity does not affect parameter estimates (as variance, although not constant, is unbiased in our case), but it does affect the estimate of standard errors and confidence intervals. However, we are not using these, and rather we assess the output using a range of other performance metrics (detailed in section 3.3).

In summary, although the assumption of homoscedasticity is being violated, it was shown that applying a monthly calibration (through 12P-ind and 12P-GB approaches), which removes the heteroscedasticity, does not improve results. Moreover, the performance of results is fully assessed using other metrics, therefore we believe that the violation of this assumption does not pose any issue in the application of OLS in our particular case.

In addition, because the variance of the residuals is not constant, we provide monthly MAPE values together with the datasets so that the users are aware of the uncertainty which varies according to the season.

The Durbin-Watson (Durbin and Watson, 1971) statistics value of 1.3 also suggests a certain degree of autocorrelation in the residuals, which is common when working with time series. But again, as with heteroscedasticity, autocorrelation tends to underestimate the standard errors, but does not bias the OLS coefficient estimates. As the standard errors and interval of confidence are not used, the moderate degree of autocorrelation does not pose problem in our particular case.

\section{References:}

Breusch, T., \& Pagan, A. (1979). A Simple Test for Heteroscedasticity and Random Coefficient Variation. Econometrica, 47(5), 1287-1294. doi:10.2307/1911963

Durbin, J., \& Watson, G. (1971). Testing for Serial Correlation in Least Squares Regression.

III. Biometrika, 58(1), 1-19. doi:10.2307/2334313 


\section{Section S2. Considerations in the joining of UKCP09-temp monthly and HD-temp monthly temperature datasets}

The temperature data used in this study to derive the temperature-based gridded PET dataset is produced by joining the following two datasets:

- UKCP09 mean monthly temperature (5-km grids, monthly time series) for 1910-2015 for the UK, including Northern Ireland (UKCP09-temp monthly). This is part of a larger dataset developed by UK Met Office, its derivation is fully described in Perry and Hollis (2005).

- HistDrought mean monthly temperature (5-km grids, monthly time series) for 1891-1909 for the UK, including Northern Ireland (HD-temp monthly). This was derived using the same methodology as UKCP09, using historic weather station data rescued by the Met Office in the Historic Droughts project (NERC grant number: NE/L01016X/1).

The joining of both datasets does not create a break in the dataset, as the exact same methodology was applied to derive the HistDroughts grids (method described in Perry and Hollis, 2005). The dataset previously only existed from 1910, as the density of stations was too sparse prior to that. However, within Historic Droughts project, historic data has been rescued and digitised by the Met Office, which has allowed them to extend the gridded temperature back to 1891 .

Possible inhomogeneities in the underlying data are considered to be minor. The gridded temperature product used in this study is a standard national product produced by the UK Met Office National Climate Information Centre (NCIC). All the underlying stations are part of the climatological network administered by the Met Office, which are subject to common observation methods, regular site inspections and instrument calibration. The data is also subject to quality control procedures prior to archiving. For all this, Prior and Perry (2014) concluded that, even if individual station records were not tested for homogeneity, the effect of inhomogeneities in the gridded product is considered minimal. The interpolation and regression methods used to create the gridded product, which takes into account factors such as latitude and longitude, altitude and terrain shape, coastal influence, and urban land use, reduces the impact of station openings and closures on homogeneity, although it can't be removed entirely, especially in areas of complex topography or sparse station coverage (Perry and Hollis, 2005).

\section{References:}

Perry, M., and Hollis, D. (2005), The generation of monthly gridded datasets for a range of climatic variables over the UK, Int. J. Climatol., 25: 1041-1054, 10.1002/joc.1161

Prior, M. J. and Perry, M. C. (2014), Analyses of trends in air temperature in the United Kingdom using gridded data series from 1910 to 2011. Int. J. Climatol., 34: 3766-3779. doi:10.1002/joc.3944 


\section{Supplementary tables:}

Table S1: MAPE for all combinations of (i) temperature-based PET equations, (ii) calibration approaches and (iii) input temperature data.

\begin{tabular}{|c|c|c|c|c|c|c|c|c|}
\hline \multirow[b]{2}{*}{$\begin{array}{l}\text { Calibration } \\
\text { approach }\end{array}$} & \multirow[b]{2}{*}{$\begin{array}{l}\text { PET } \\
\text { equation }\end{array}$} & \multicolumn{7}{|c|}{ Input temperature data } \\
\hline & & $\begin{array}{c}\text { CHESS- } \\
\text { temp } \\
\text { daily }\end{array}$ & $\begin{array}{c}\text { CHESS- } \\
\text { temp } \\
\text { clim }\end{array}$ & $\begin{array}{c}\text { CHESS- } \\
\text { temp } \\
\text { monthly } \\
\text { I } \\
\end{array}$ & $\begin{array}{c}\text { CHESS- } \\
\text { temp } \\
\text { monthly } \\
\text { II } \\
\end{array}$ & $\begin{array}{c}\text { CHESS- } \\
\text { temp } \\
\text { monthly } \\
\text { III } \\
\end{array}$ & $\begin{array}{c}\text { UKCP09- } \\
\text { temp } \\
\text { monthly } \\
\text { I }\end{array}$ & $\begin{array}{c}\text { UKCP09- } \\
\text { temp } \\
\text { monthly } \\
\text { II } \\
\end{array}$ \\
\hline \multirow{7}{*}{ 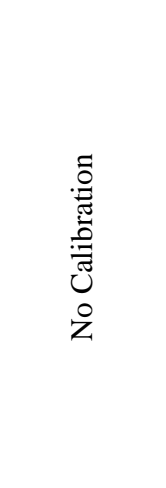 } & Hamon & 34.73 & 36.99 & 34.98 & 35.23 & 34.84 & & \\
\hline & $\begin{array}{l}\text { McGuinness- } \\
\text { Bordne }\end{array}$ & 75.12 & 80.46 & 75.18 & 75.80 & 75.28 & & \\
\hline & $\begin{array}{l}\text { Blaney- } \\
\text { Criddle }\end{array}$ & 60.88 & 61.77 & 58.33 & 58.89 & 57.63 & & \\
\hline & Kharrufa & 66.52 & 67.80 & 63.88 & 64.57 & 63.09 & & \\
\hline & Oudin & 38.57 & 40.42 & 38.59 & 38.86 & 38.45 & & \\
\hline & MOHYSE & 51.47 & 48.16 & 49.03 & 48.89 & 47.97 & & \\
\hline & Thornthwaite & 48.74 & 47.74 & 47.05 & 47.46 & 46.61 & & \\
\hline \multirow{4}{*}{$\begin{array}{l}\text { Oै } \\
\varrho^{\prime}\end{array}$} & Hamon & 36.24 & 36.73 & 36.39 & 36.60 & 35.61 & & \\
\hline & $\begin{array}{l}\text { McGuinness- } \\
\text { Bordne }\end{array}$ & 32.02 & 32.58 & 32.02 & 32.14 & 31.67 & 31.65 & 32.06 \\
\hline & $\begin{array}{l}\text { Blaney- } \\
\text { Criddle }\end{array}$ & 38.69 & 37.63 & 37.70 & 37.90 & 37.07 & & \\
\hline & Kharrufa & 35.04 & 36.24 & 36.51 & 36.41 & 35.48 & & \\
\hline \multirow{4}{*}{$\begin{array}{l}0 \\
\vdots \\
\stackrel{1}{ } \\
\text { In }\end{array}$} & Hamon & 37.22 & 37.89 & 37.50 & 37.65 & 37.60 & & \\
\hline & $\begin{array}{l}\text { McGuinness- } \\
\text { Bordne }\end{array}$ & 32.11 & 32.50 & 32.02 & 32.14 & 32.07 & & \\
\hline & $\begin{array}{l}\text { Blaney- } \\
\text { Criddle } \\
\end{array}$ & 39.41 & 38.47 & 38.53 & 38.71 & 37.98 & & \\
\hline & Kharrufa & 36.38 & 37.31 & 37.65 & 37.59 & 37.48 & & \\
\hline \multirow{4}{*}{$\begin{array}{l}\overrightarrow{7} \\
\stackrel{7}{=}\end{array}$} & Hamon & 36.37 & 36.77 & 36.39 & 36.60 & 35.59 & & \\
\hline & $\begin{array}{l}\text { McGuinness- } \\
\text { Bordne }\end{array}$ & 32.20 & 32.61 & 32.16 & 32.27 & 31.78 & & \\
\hline & $\begin{array}{l}\text { Blaney- } \\
\text { Criddle }\end{array}$ & 38.59 & 37.50 & 37.60 & 37.80 & 36.95 & & \\
\hline & Kharrufa & 34.88 & 37.87 & 36.92 & 36.72 & 35.74 & & \\
\hline \multirow{4}{*}{ 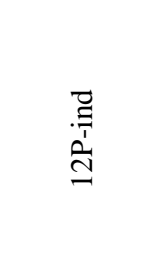 } & Hamon & 37.50 & 38.14 & 37.65 & 37.80 & 37.76 & & \\
\hline & $\begin{array}{l}\text { McGuinness- } \\
\text { Bordne }\end{array}$ & 32.45 & 32.63 & 32.28 & 32.39 & 32.32 & & \\
\hline & $\begin{array}{l}\text { Blaney- } \\
\text { Criddle } \\
\end{array}$ & 39.36 & 38.44 & 38.50 & 38.67 & 37.95 & & \\
\hline & Kharrufa & 36.22 & 39.30 & 38.06 & 37.89 & 37.91 & & \\
\hline
\end{tabular}


Table S2: NSE for all combinations of (i) temperature-based PET equations, (ii) calibration approaches and (iii) input temperature data.

\begin{tabular}{|c|c|c|c|c|c|c|c|c|}
\hline \multirow[b]{2}{*}{$\begin{array}{l}\text { Calibration } \\
\text { approach }\end{array}$} & \multirow[b]{2}{*}{$\begin{array}{l}\text { PET } \\
\text { equation }\end{array}$} & \multicolumn{7}{|c|}{ Input temperature data } \\
\hline & & $\begin{array}{c}\text { CHESS- } \\
\text { temp } \\
\text { daily }\end{array}$ & $\begin{array}{c}\text { CHESS- } \\
\text { temp } \\
\text { clim }\end{array}$ & $\begin{array}{c}\text { CHESS- } \\
\text { temp } \\
\text { monthly } \\
\text { I } \\
\end{array}$ & $\begin{array}{c}\text { CHESS- } \\
\text { temp } \\
\text { monthly } \\
\text { II } \\
\end{array}$ & $\begin{array}{c}\text { CHESS- } \\
\text { temp } \\
\text { monthly } \\
\text { III }\end{array}$ & $\begin{array}{c}\text { UKCP09- } \\
\text { temp } \\
\text { monthly } \\
\text { I } \\
\end{array}$ & $\begin{array}{c}\text { UKCP09- } \\
\text { temp } \\
\text { monthly } \\
\text { II }\end{array}$ \\
\hline \multirow{7}{*}{ 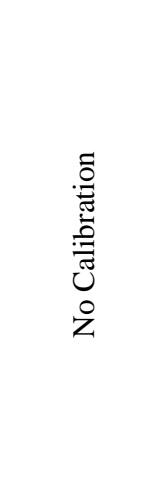 } & Hamon & 0.673 & 0.619 & 0.661 & 0.656 & 0.663 & & \\
\hline & $\begin{array}{l}\text { McGuinness- } \\
\text { Bordne }\end{array}$ & -0.430 & -0.592 & -0.401 & -0.424 & -0.405 & & \\
\hline & $\begin{array}{l}\text { Blaney- } \\
\text { Criddle }\end{array}$ & 0.163 & 0.107 & 0.222 & 0.211 & 0.238 & & \\
\hline & Kharrufa & -0.124 & -0.118 & 0.028 & 0.008 & 0.053 & & \\
\hline & Oudin & 0.661 & 0.608 & 0.649 & 0.644 & 0.651 & & \\
\hline & MOHYSE & -0.388 & -0.307 & -0.318 & -0.309 & -0.269 & & \\
\hline & Thornthwaite & 0.406 & 0.432 & 0.458 & 0.451 & 0.466 & & \\
\hline \multirow{4}{*}{$\begin{array}{l}\text { Oै } \\
\text { ڤ }\end{array}$} & Hamon & 0.662 & 0.631 & 0.642 & 0.640 & 0.655 & & \\
\hline & $\begin{array}{l}\text { McGuinness- } \\
\text { Bordne }\end{array}$ & 0.738 & 0.709 & 0.720 & 0.719 & 0.722 & 0.720 & 0.720 \\
\hline & $\begin{array}{l}\text { Blaney- } \\
\text { Criddle }\end{array}$ & 0.626 & 0.621 & 0.626 & 0.627 & 0.638 & & \\
\hline & Kharrufa & 0.510 & 0.581 & 0.531 & 0.536 & 0.546 & & \\
\hline \multirow{4}{*}{ 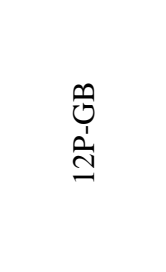 } & Hamon & 0.643 & 0.609 & 0.623 & 0.622 & 0.628 & & \\
\hline & $\begin{array}{l}\text { McGuinness- } \\
\text { Bordne }\end{array}$ & 0.736 & 0.709 & 0.719 & 0.719 & 0.720 & & \\
\hline & $\begin{array}{l}\text { Blaney- } \\
\text { Criddle }\end{array}$ & 0.610 & 0.604 & 0.609 & 0.611 & 0.622 & & \\
\hline & Kharrufa & 0.461 & 0.552 & 0.494 & 0.499 & 0.512 & & \\
\hline \multirow{4}{*}{$\begin{array}{l}\vec{\Xi} \\
\stackrel{\vec{T}}{=}\end{array}$} & Hamon & 0.657 & 0.634 & 0.644 & 0.642 & 0.658 & & \\
\hline & $\begin{array}{l}\text { McGuinness- } \\
\text { Bordne }\end{array}$ & 0.737 & 0.711 & 0.722 & 0.721 & 0.724 & & \\
\hline & $\begin{array}{l}\text { Blaney- } \\
\text { Criddle }\end{array}$ & 0.628 & 0.625 & 0.629 & 0.630 & 0.641 & & \\
\hline & Kharrufa & 0.521 & 0.596 & 0.550 & 0.555 & 0.569 & & \\
\hline \multirow{4}{*}{ 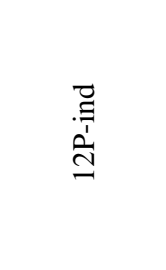 } & Hamon & 0.631 & 0.607 & 0.622 & 0.621 & 0.627 & & \\
\hline & $\begin{array}{l}\text { McGuinness- } \\
\text { Bordne }\end{array}$ & 0.733 & 0.710 & 0.720 & 0.719 & 0.721 & & \\
\hline & $\begin{array}{l}\text { Blaney- } \\
\text { Criddle }\end{array}$ & 0.611 & 0.606 & 0.611 & 0.613 & 0.624 & & \\
\hline & Kharrufa & 0.474 & 0.569 & 0.517 & 0.523 & 0.538 & & \\
\hline
\end{tabular}




\section{Supplementary Figures:}
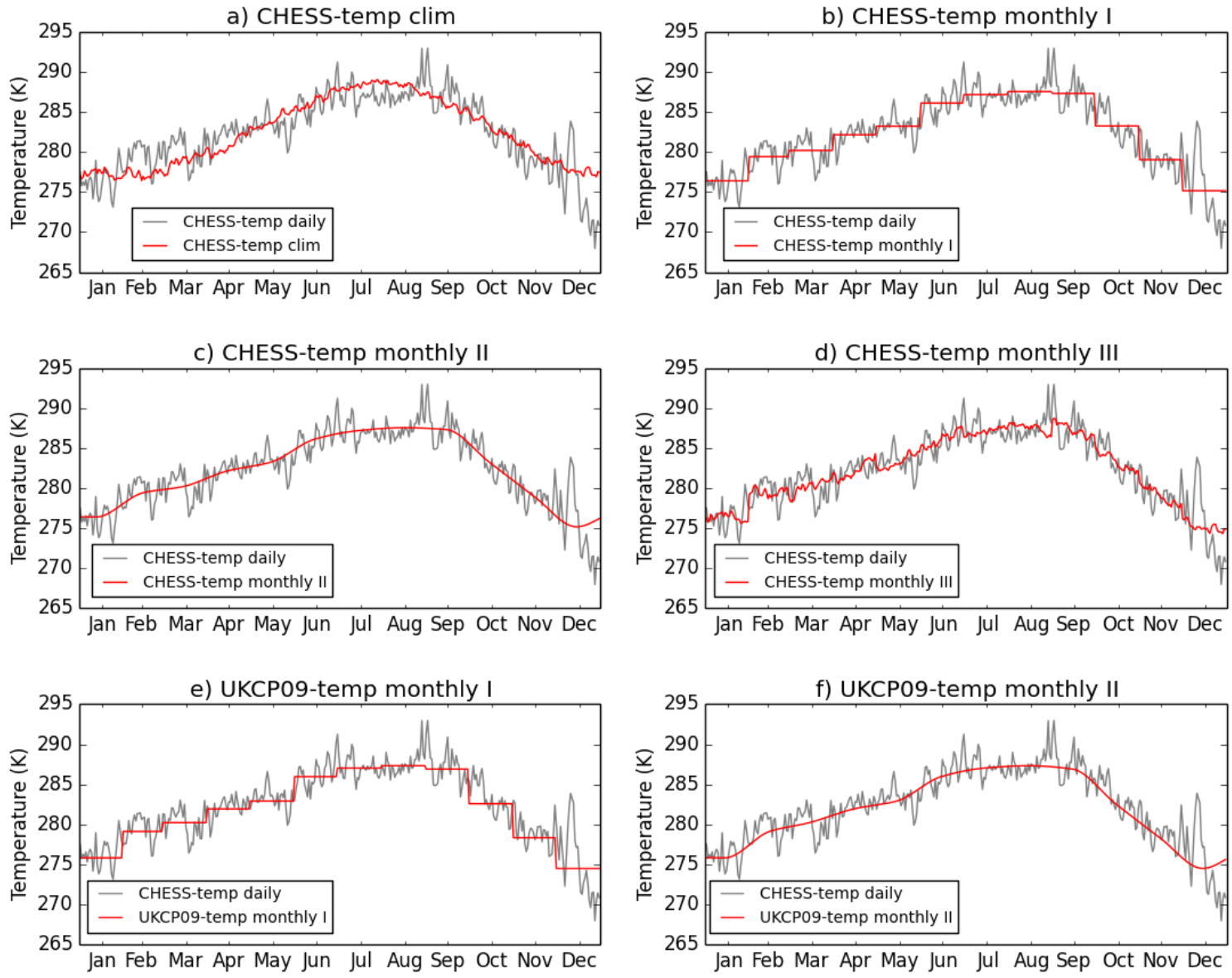

Fig.S1: Illustration of the different input temperature data used for an example year (1961) and an example catchment (NRFA catchment code: 55023, Wye at Redbrook). On all plots, the grey line is the daily CHESS temperature data (CHESS-temp daily). The alternative temperature input data tested in the current study (red lines on plots) are: a) CHESS-temp clim, which is the long term average (1961-1990) of daily mean temperature, derived from CHESS-temp daily; b) CHESS-temp monthly I, which is monthly temperature (from CHESS) disaggregated to daily uniformly for each month; c) CHESS-temp monthly II, which is monthly temperature (from CHESS) disaggregated to daily using pchip interpolation method; d) CHESS-temp monthly III, which is monthly temperature (from CHESS) disaggregated to daily using CHESS daily mean temperature climatology pattern. Effectively, a) and d) are different because in d), the time series have been shifted for each month so that the monthly mean temperature matches the observed monthly temperature. Finally, e) and f) are respectively the same as b) and c), but using UKCP09 (5-km) monthly temperature instead of CHESS (1-km). 
a) Spatial coverage of

CHESS dataset

(temperature and PET)

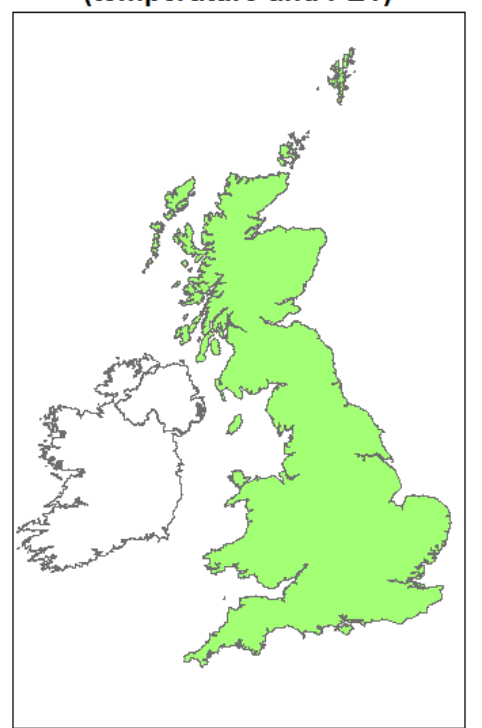

b) Spatial coverage of UKCP09 temperature data and historic PET dataset

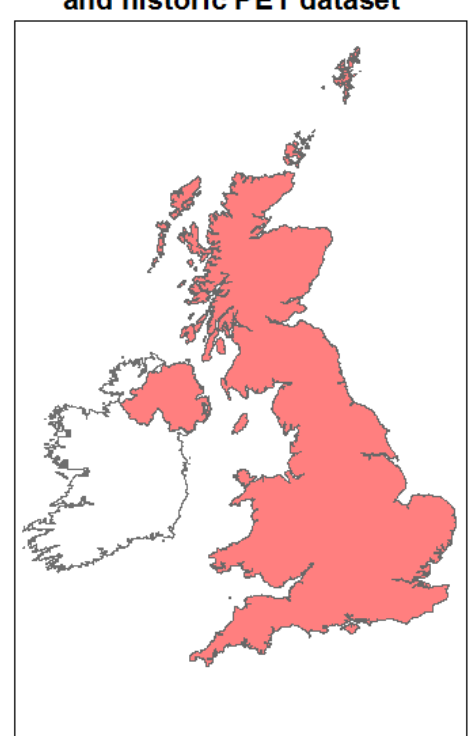

c) Great Britain,

Northern Ireland and United Kingdom

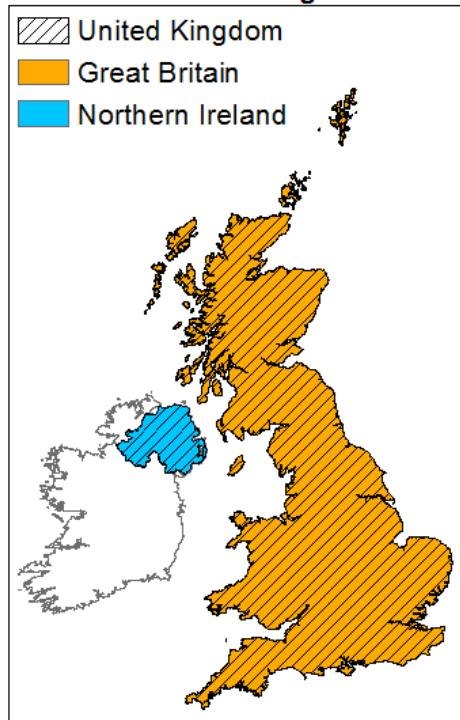

Figure S2: Spatial coverage of different datasets used in this study: (a) Spatial coverage of CHESS dataset (both temperature and PET data), which covers Great Britain only; (b) Spatial coverage of UKCP09 temperature and the final PET product, which both cover the whole of United Kingdom, including Northern Ireland; and (c) map showing geographical distinction between Great Britain, Northern Ireland and United Kingdom. 

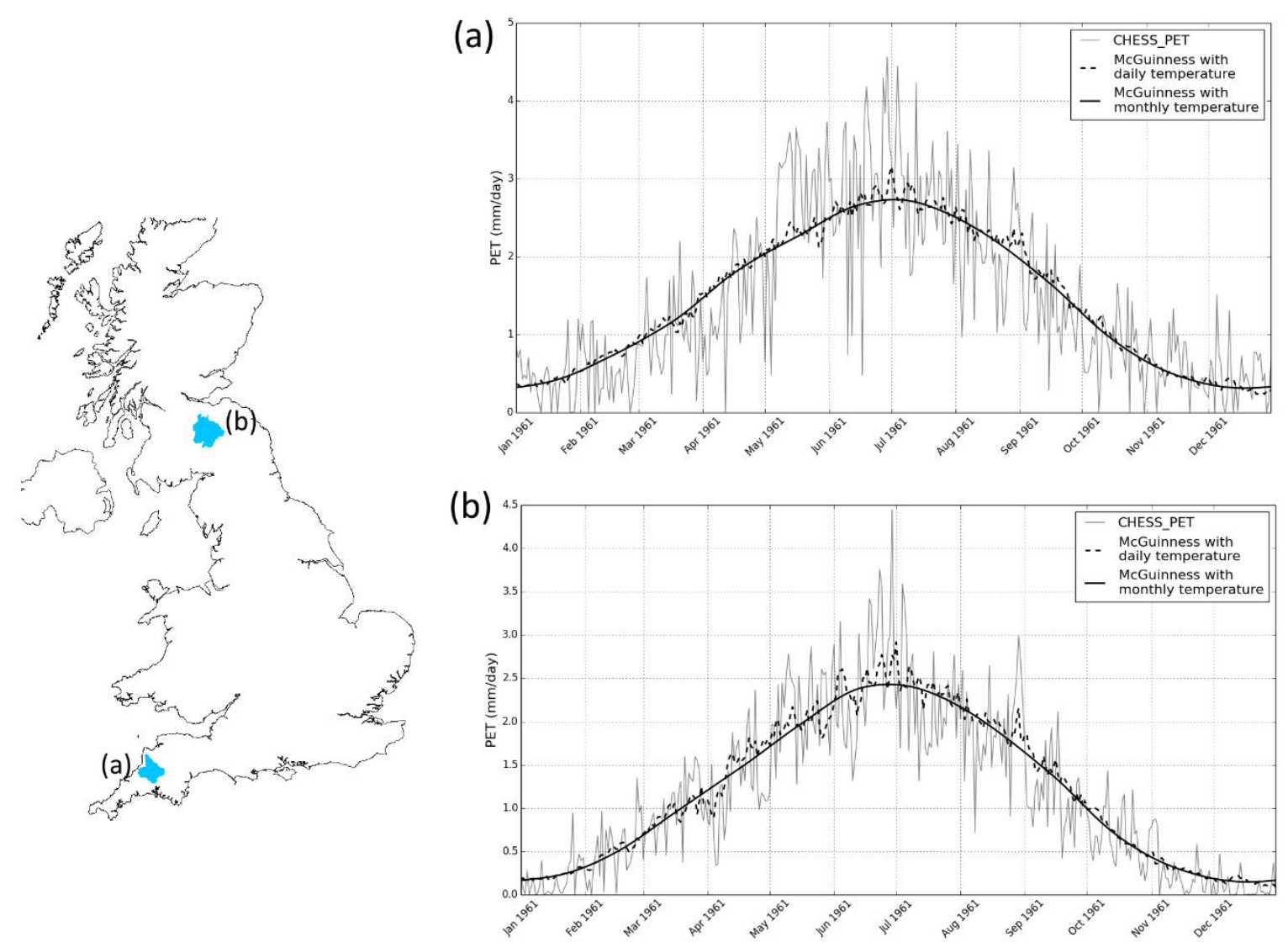

Figure S3: Comparison of different PET estimations for two example catchments ((a) river Tamar in South-West England and (b) river Tweed in Scotland) and a typical example year (1961). Difference in daily variability of PET can be observed between the different versions of PET. 


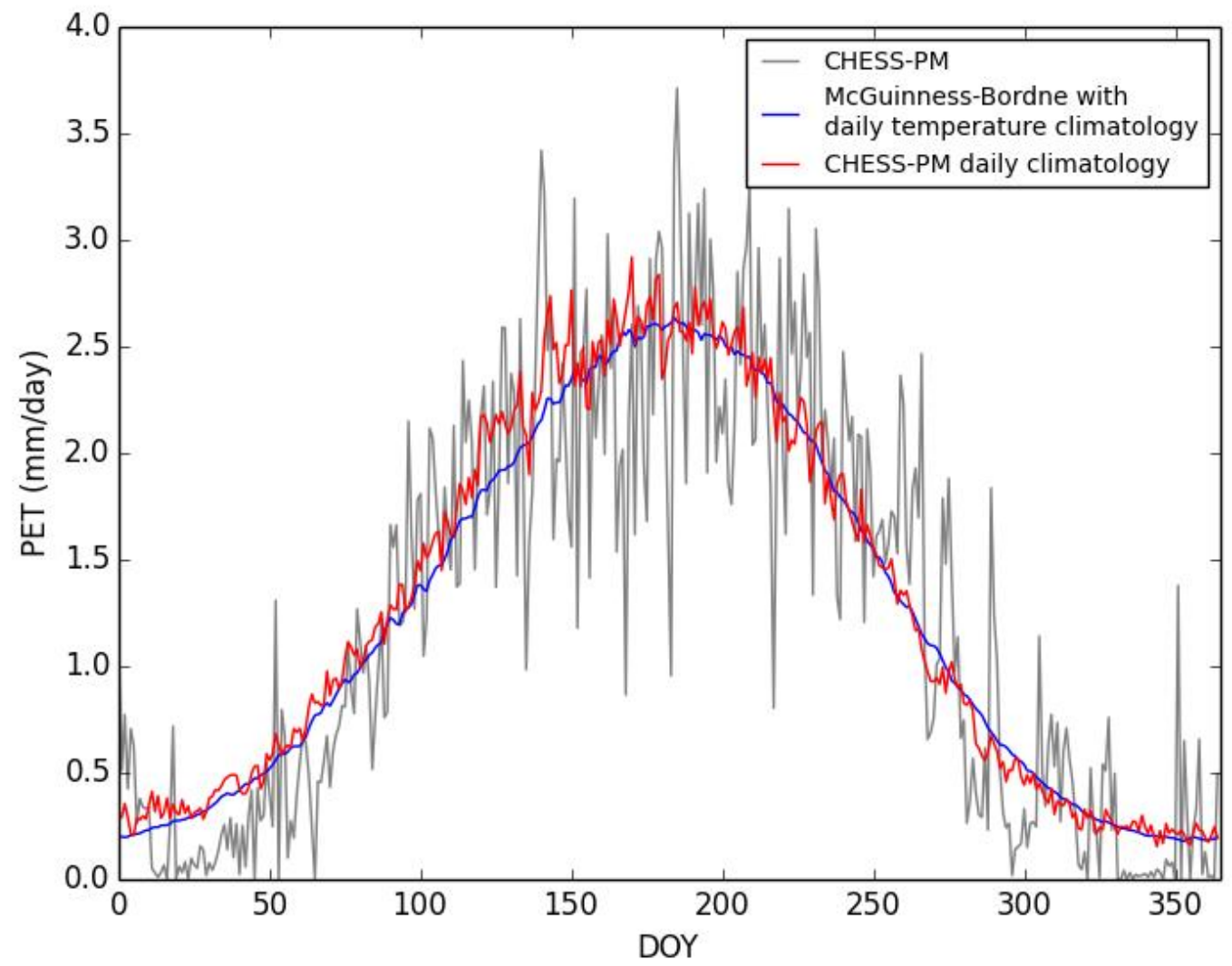

Fig.S4: Daily PET time series for an example catchment (23001), year 1991, to illustrate the differences between (i) CHESS-PM, proxy to observed PET (grey line), (ii) PET calculated using McGuinness-Bordne equation, using CHESS daily temperature climatology (long term average from 1961-1990) (blue line), and (iii) CHESS-PM daily climatology (long term average from 1961-1990) (red line). 

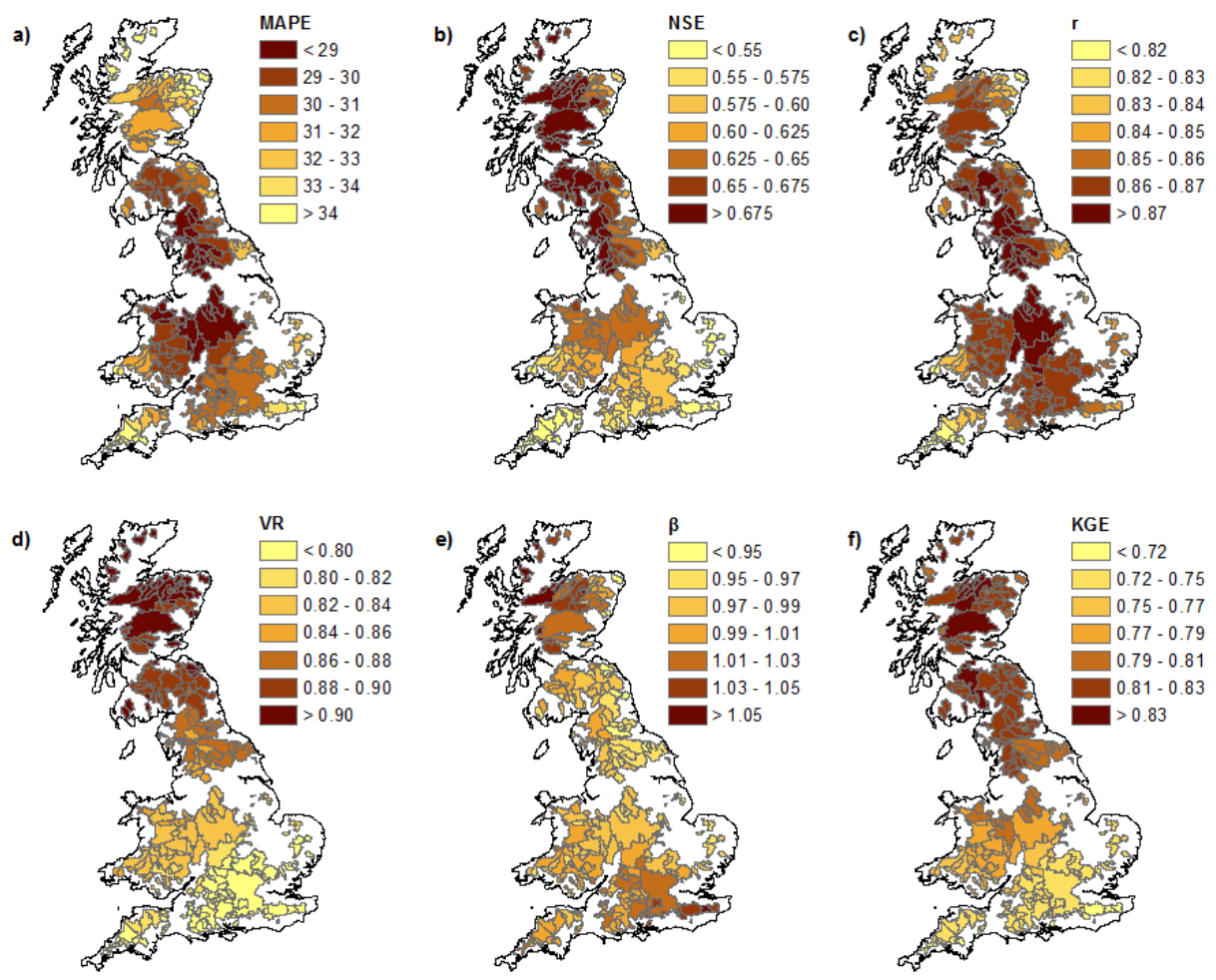

Figure S5: Evaluation metrics for daily PET dataset for the 306 evaluation catchments. The darker the colour, the better the performance for all metrics represented, except for the Bias ratio ( $\beta$ ) (Fig. A5e) where the middle-range colour is optimal.
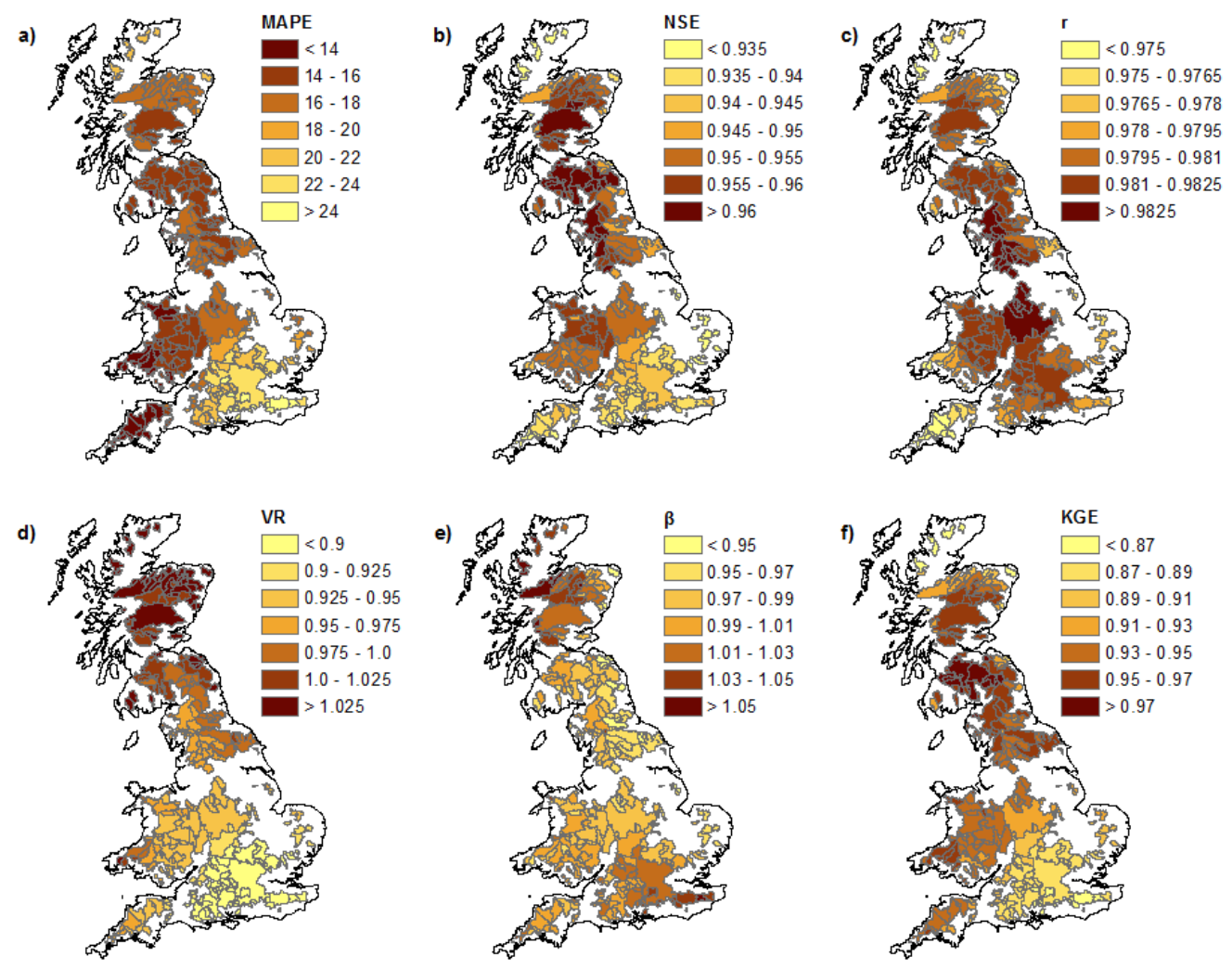

Figure S6: Evaluation metrics for monthly PET dataset for the 306 evaluation catchments. The darker the colour, the better the performance for all metrics represented, except for the Variability Ratio (VR) (Fig. A5d) where 1 is the optimum, and the Bias ratio ( $\beta$ ) (Fig. A6e) where the middle-range colour is optimal. 